\title{
Potential risk of drift from inclined fan nozzles
}

\author{
Eder D. de Moraes ${ }^{1}$, Otávio J. G. A. Saab ${ }^{1}$, Marco A. Gandolfo², \\ Rodrigo Y. P. Marubayashi ${ }^{1} \&$ Ulisses D. Gandolfo ${ }^{3}$
}

${ }^{1}$ Universidade Estadual de Londrina/Centro de Ciências Agrárias/Departamento de Agronomia. Londrina, PR, Brasil. E-mail: ederdiasdemoraes@gmail.com
(Corresponding author) - ORCID: 0000-0002-0977-2328; abisab@uel.br - ORCID:0000-0002-1757-636X; marubayashi@uel.br-ORCID:0000-0003-2778-8654
${ }^{2}$ Universidade Estadual do Norte do Paraná/Campus Luiz Meneghel/Departamento de Engenharia e Desenvolvimento Agrário. Bandeirantes, PR, Brasil.
E-mail: gandolfo@uenp.edu.br - ORCID: 0000-0003-2314-3752
${ }^{3}$ Instituto Dashen Ltda. Bandeirantes, PR, Brasil. E-mail: ulisses@institutodashen.com.br - ORCID: 0000-0001-6131-0289

ABSTRACT: Pest, disease and weed control in large-scale crops depend on the application of agrochemicals. These applications are subject to several factors that can lead to drift. The objective of this study was to evaluate the effect of spray nozzles with inclined flat jet, on the drift. The drift was collected in a $10 \mathrm{~m}$ wind tunnel, with a spray system inside. The samples were collected in 5 horizontal points, from 2.0 to $6.0 \mathrm{~m}$ away from the spray nozzle and 5 points in the vertical, from 0.1 to $0.5 \mathrm{~m}$ away from the lower base of the wind tunnel, totaling 25 sample points. The mixture applied was glyphosate (isopropylamine salt, $1080 \mathrm{~g}$ a.e. ha-1) with 2,4-D (dimethylamine salt, 1.005 g a.e. ha ${ }^{-1}$ ). The nozzles J3D 100 025, JGC 120 02, JAP 110015 and ADI 110 015 (control), inclined by $37.5^{\circ}, 20^{\circ}, 15^{\circ}$ and $0^{\circ}$, respectively, were used in two directions of spray: upwind and downwind of the air flow direction. The nozzles J3D, JGC and JAP, when inclined downwind reduced the drift by 16.1, 2.6 and 39.0\%, respectively, relative to the control, and when inclined upwind, reduced drift by $53.4,3.9$ and $18.6 \%$, respectively, relative to the control. Spray nozzles with second-generation air-induction inclined flat jet (JAP) and standard inclined flat jet (J3D) reduce the collected drift compared to the nozzle without inclination, regardless of wind flow direction.

Key words: wind tunnel, environmental contamination, phytosanitary control, J3D

\section{Potencial risco de deriva de pontas de pulverização de jato plano inclinado}

RESUMO: O controle de pragas, doenças e plantas daninhas nas culturas de larga escala dependem da aplicação de produtos fitossanitários. Estas aplicações estão sujeitas a diversos fatores que podem levar à deriva. O objetivo deste trabalho foi avaliar a deriva de pontas de pulverização de jato plano inclinado. A deriva foi coletada em túnel de vento de $10 \mathrm{~m}$ de comprimento, com sistema de pulverização no seu interior. As coletas foram efetuadas em cinco pontos na horizontal, de 2,0 a 6,0 m, da ponta de pulverização e cinco pontos na vertical, de 0,1 a $0,5 \mathrm{~m}$ da base inferior do túnel de vento, totalizando 25 pontos amostrais. A calda aplicada foi a mistura de glyphosate (sal de isopropilamina, $1.080 \mathrm{~g}$ e.a. ha $\mathrm{h}^{-1}$ ) com 2,4-D (sal dimetilamina, 1.005 g e.a. ha ${ }^{-1}$ ). Foram utilizadas as pontas J3D 100 025, JGC 120 02, JAP 110015 e ADI 110 015 (testemunha), com $37,5^{\circ}, 20^{\circ}, 15^{\circ}$ e $0^{\circ}$ de inclinação, respectivamente, em dois sentidos de pulverização: contra e a favor do sentido do fluxo de ar. As pontas J3D, JGC e JAP, quando inclinadas a favor do fluxo de vento reduziram a deriva em 16,1, 2,6 e 39,0\%, respectivamente, em relação à testemunha, e quando inclinadas contra o fluxo, reduziram a deriva em 53,4, 3,9 e 18,6\%, respectivamente. Pontas de pulverização de jato plano inclinado com indução a ar de segunda geração (JAP) e jato plano padrão inclinado (J3D), reduzem a deriva em relação à ponta sem inclinação, independente do sentido de fluxo de vento.

Palavras-chave: túnel de vento, contaminação ambiental, controle fitossanitário, J3D

Ref. 192961 - Received 15 Mar, 2018 • Accepted 30 Nov, 2018 • Published 30 Jan, 2019 


\section{INTRODUCTION}

Large-scale agriculture is supported by the application of phytosanitary products, that require the use of safe and efficient products, as well as application techniques that allow such needs to be met (Simões et al., 2009), without disregarding the concern about enhancing the production process to reduce environmental impacts (Teixeira et al., 2010).

To reduce environmental impacts in the application of phytosanitary products, measures to minimize drift should be adopted. Considered as the deviation of particles or droplets of reduced size formed during spraying which do not reach the target or targeted area (Matuo, 1990), drift is also one of the main causes of financial losses due to either direct loss of herbicides or contaminations of sensitive crops located nearby.

One of the techniques to reduce drift is the selection of spray nozzles, mainly because of the size of droplets (Costa et al., 2012). Other authors report that drift is directly related to VMD (volumetric mean diameter) (Oliveira \& Antuniassi, 2012; França et al., 2017) and to the percentage of droplets smaller than $100 \mu \mathrm{m}(\%<100)$ (Oliveira \& Antuniassi, 2012; Mota, 2015).

Another strategy to decrease the potential risk of drift can be the use of models of spray nozzles with inclined flat jet. Madureira et al. (2015) report that, theoretically, spray nozzles with jet inclined windward may help reduce drift because the spray nozzle jet is less affected by the operation speed of the sprayer, reducing the displacement of droplets to unwanted locations.

Every year new models of spray nozzles are launched and become alternatives to the management used by the farmer, but there is little information on the applicability of these new devices. Given such lack of studies related to new models of hydraulic nozzles and the importance of selecting technologies to minimize the risks of herbicide drift, the present study aimed to evaluate the effect of models of spray nozzles with inclined flat jet, at different angles, on the drift of glyphosate + 2,4-D (dimethylamine).

\section{Material ANd Methods}

Drift was collected in a wind tunnel, adapted according to the recommendations of the norm ISO 22856 (ISO, 2008). In this method, an air current hits the spray and drift is caught by artificial targets, composed of 2-mm-diameter nylon threads located $2 \mathrm{~m}$ away from the spray nozzle, totaling 5 points of collection in the set of tests, which are placed $1.0 \mathrm{~m}$ apart. At each point of collection, five threads were placed at heights of $0.1,0.2,0.3,0.4$ and $0.5 \mathrm{~m}$ from the internal base of the tunnel, in order to collect the vertical profile. Therefore, there were 25 samples in each replicate and their mean was used to represent one replicate. The model of wind tunnel used had an open-circuit design, in which there is no air recirculation, with a $2-\mathrm{m}^{2}$ rectangular section, $1 \mathrm{~m}$ high and $2 \mathrm{~m}$ long.

Applications were performed at ambient temperature of $28.1{ }^{\circ} \mathrm{C} \pm 2.2$, relative air humidity of $60 \% \pm 7.0$ and wind speed of $2.05 \mathrm{~m} \mathrm{~s}^{-1} \pm 0.15$, in four replicates.

The mixture used in this experiment was isopropylamine salt (Roundup Original $^{\circledR}$ ) 1.080 g a.e. $\mathrm{ha}^{-1}+2,4$-D, dimethylamine salt (DMA $806 \mathrm{BR}^{\circledast}$ ) $1.005 \mathrm{~g}$ a.e. ha ${ }^{-1}$. The Brilliant Blue marker FCF - INS 133 (International Numbering System for Food
Additives), also known by its North-American denomination, FD\&C Blue n.1 (Food, Drug \& Cosmetic), was added to the mixture at concentration of $6 \mathrm{~g} \mathrm{~L}^{-1}$, diluted in distilled water.

The spray nozzles used were: standard inclined flat jet, model J3D $100025^{\circ}$; inclined flat jet with pre-orifice, model JGC $12002^{\circ}$; second-generation air-induction inclined flat jet, model JAP $110015^{\circ}$ and, as a control, flat jet with pre-orifice, model ADI $110015^{\circ}$. The angles of the nozzles according to the manufacturer are: $37.5^{\circ}, 20^{\circ}, 15^{\circ}$ and $0^{\circ}$, respectively (JACTO, 2017). Service pressures were: $151.8,227.7,414$ and $414 \mathrm{kPa}$, respectively, to obtain flow rate of $0.69 \mathrm{~L} \mathrm{~min}^{-1}$. The droplet size class of all nozzles was medium, according to the manufacturer.

Drift collections were conducted in two directions of jet inclination: one with nozzles inclined against the wind flow direction (upwind), and the other in the same direction of the wind flow (downwind).

The spraying system comprised a $\mathrm{CO}_{2}$-pressurized circuit, with spray nozzle installed at $0.5 \mathrm{~m}$ height from the internal base of the tunnel.

Spraying was kept for $30 \mathrm{~s}$ to contaminate the collectors. At the end of each repetition, electric engines installed inside the tunnel, in each horizontal collector, were turned on to move the collectors and withdrawn the section of threads which received the drift occurred during the spraying.

As the collectors were moved, they entered a washing chamber which is actuated simultaneously to the electric engines. This chamber has two jets of distilled water for an efficient washing and complete removal of all marker attached onto the collector while it is being moved.

The liquid obtained during collector washing was conducted through a pipe to a plastic cup. The solutions from the samples were analyzed in spectrophotometer to quantify absorbance values at $630 \mathrm{~nm}$ and, after that, the levels of markers were determined in each sample.

Absorbance values were standardized for the $100 \mathrm{~mL}$ volume using Eq. 1:

$$
\mathrm{Ac}=\frac{(\mathrm{V} \text { abs })}{100}
$$

where:

Ac - corrected absorbance, $\mathrm{nm}$;

$\mathrm{V}$ - sample volume, $\mathrm{mL}$; and,

abs - absorbance found in the sample, $\mathrm{nm}$.

The standard curve was prepared by collecting samples from each mixture. Twenty dilutions were made and absorbance was determined in each dilution. The equation of the line and marker concentration in each sample were obtained using Eq. 2:

$$
\mathrm{C}=\mathrm{Ac} \text { eq }
$$

where:

C - marker concentration, $\mu$;

Ac - corrected absorbance, $\mathrm{nm}$; and,

eq - equation of the line for the mixture.

Marker concentration $(\mu \mathrm{g})$ was divided by the collector area to determine the specific deposition $\left(\mu \mathrm{g} \mathrm{mm}^{-2}\right)$, Eq. 3: 


$$
\mathrm{De}=\mathrm{C}(2 \pi \mathrm{R} \mathrm{CL})^{-1}
$$

where:

De - specific deposition, $\mu \mathrm{g} \mathrm{mm}^{-2}$;

C - marker concentration, $\mu \mathrm{g}$;

$\mathrm{R}$ - collector radius, $\mathrm{mm}$; and,

$\mathrm{CL}$ - collector length, $\mathrm{mm}$.

Droplet spectrum was characterized using an image-based particle analyzer, model VisiSize Portable P15 (Oxford Lasers, Imaging Division, Oxford, U.K.). The characterization was performed in real time by a software program, Visisize Particle Sizing, developed by the same manufacturer of the device.

During the evaluations, the option of lens $n^{\circ} 3$ was selected in the magnification 2 . With these settings, the device was able to measure droplets from 21 to $5650 \mu \mathrm{m}$. The droplets were sampled $50 \mathrm{~cm}$ below the spray nozzle and at least 10,000 droplets were analyzed for each one of the four replicates of each treatment. Evaluations were conducted at only one area of the spray jet, in the center, and the area analyzed by the device was 5656 x $5656 \mathrm{~mm}$ (width $\mathrm{x}$ height). In this method, a LED light was used to illuminate the region of interest of the droplet spectrum and a digital camera captured the images based the shades of the droplets. The areas of the images which were within the focus region of the camera were analyzed by the program VisiSize.

The system analyzes up to 1,000 droplets per image, depending on the size of the droplets passing by the camera's region of capture. The program distinguishes and eliminates the images of droplets that may be overlapped or in contact (coalescent) from the images.

Among the parameters evaluated by the device, the volumetric mean diameter (VMD) and percentage of droplets smaller than $100 \mu \mathrm{m}(\%<100 \mu \mathrm{m})$ were selected to characterize the droplet spectrum.

Droplet spectrum was analyzed using the same mixture, pressure and spray nozzles of the drift experiment.

Drift was analyzed in randomized block design, in a 4 (spray nozzles) x 2 (wind flow direction) factorial arrangement. A completely randomized design was used in the droplet spectrum experiment. For all data, normality was checked with Shapiro-Wilk test $(\mathrm{p}<0.05)$ and homogeneity of variance with Lavene test. Means were compared by the confidence interval (CI 95\%). Pearson correlation ( $\mathrm{p}<0.05$ ) was used to check the associations between drift and the other variables.

\section{Results AND Discussion}

The values of collected drift and drift percentage variation relative to the control, when the inclination angle of the spray nozzles is positioned downwind and upwind in relation to the wind flow direction, are presented in Figure 1.

In the analysis of drift collected when the nozzles were positioned downwind, the results indicate lower values of drift for the second-generation air-induction spray nozzle (JAP, $\left.15^{\circ}\right)$, followed by the inclined flat jet $\left(\mathrm{J} 3 \mathrm{D}, 37.5^{\circ}\right)$, inclined flat jet with pre-orifice (JGC, $20^{\circ}$ ) and flat jet with pre-orifice $\left(\mathrm{ADI}, 0^{\circ}\right)$. The nozzles JGC and ADI did not show statistical difference.

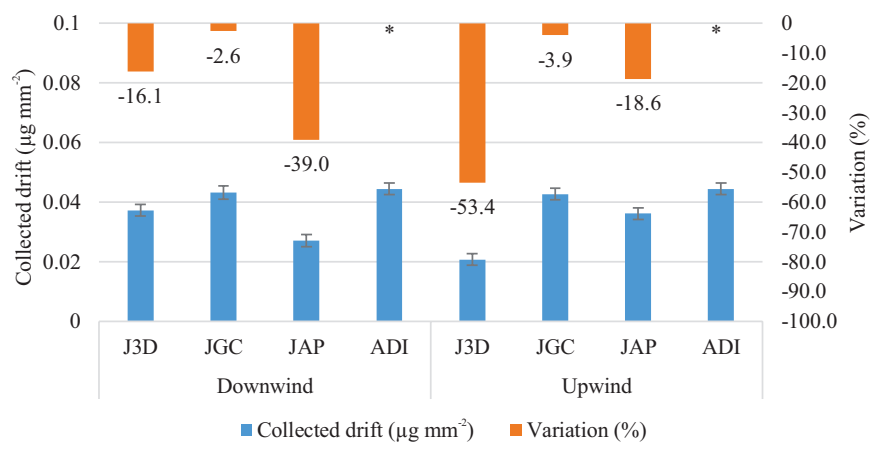

Error bars indicate the confidence interval (Cl 95\%)

Figure 1. Collected drift and drift variation percentage relative to the control (ADI nozzle), downwind and upwind

The results obtained in the present study corroborate those found by Chechetto \& Antuniassi (2012), Chechetto et al. (2013) and Madureira et al. (2015), who evaluated drift in wind tunnel and concluded that the air-induction nozzle led to lower values of drift in comparison to other models of spray nozzle.

The nozzle JAP ( $15^{\circ}$ of inclination) reduced drift by $39.0 \%$ compared to the control, which may not be related to the inclination angle, since the nozzle J3D, with inclination of $37.5^{\circ}$, led to reduction of $16.1 \%$ in comparison to the control. In theory, in this type of test using a wind tunnel, the more inclined the angle of the jet, the greater the drift collected, because the projection of the jet is close to the points of collection. This hypothesis was not confirmed in the present study.

By analyzing the behavior of the drift, when the nozzles were positioned upwind, it was possible to observe that the nozzle J3D led to the lowest collected drift among all nozzles, followed by JAP, JGC and ADI (control), and the latter two showed no statistical difference. The values of drift caused by the nozzle $\mathrm{J} 3 \mathrm{D}$ may be related to the inclination angle and greater distance between the point of collection and the projection of the jet.

The factors jet inclination and wind flow direction influenced the collected drift, since different values of collected drift were found for the two airflow directions.

The results of volumetric mean diameter for the spray nozzles tested are presented in Figure 2. The spray nozzle JAP showed VMD of $166 \mu \mathrm{m}$, which was the highest value, followed by J3D $(147 \mu \mathrm{m})$, JGC $(145 \mu \mathrm{m})$ and ADI $(134 \mu \mathrm{m})$. The spray nozzles J3D and JGC did not show statistical difference.

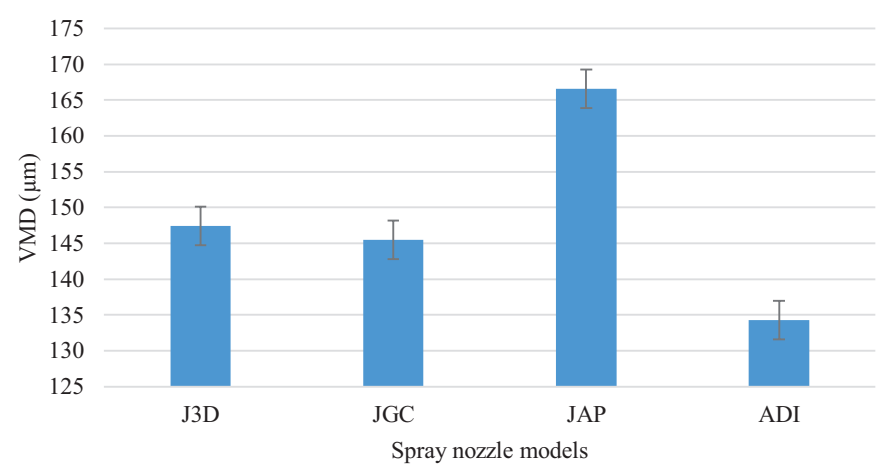

Error bars indicate the confidence interval ( $\mathrm{Cl}$ 95\%)

Figure 2. Volumetric mean diameter (VMD) of the spray nozzles with inclined flat jet (J3D), inclined flat jet with pre-orifice (JGC), second-generation air-induction inclined flat jet (JAP) and flat jet with pre-orifice (ADI) 
The percentages of droplets smaller than $100 \mu \mathrm{m}$ are presented in Figure 3. The spray nozzle with pre-orifice, model ADI, showed the highest percentage of droplets smaller than $100 \mu \mathrm{m}(26.5 \%)$, while the nozzle JAP showed the lowest percentage (15.5\%). Similar results for the nozzle with preorifice were found by Godinho Junior et al. (2017), value of $20.41 \%$. The nozzles J3D and JGC showed $21.5 \%$ of droplets smaller than $100 \mu \mathrm{m}$ and did not differ statistically.

Several authors have reported that drift is directly related to VMD (Oliveira \& Antuniassi, 2012; Oliveira et al., 2015; França et al., 2017) and percentage of droplets smaller than 100 $\mu \mathrm{m}(\%<100 \mu \mathrm{m})$ (Cunha et al., 2010; Oliveira \& Antuniassi, 2012; Mota, 2015; Oliveira et al., 2015), and this is evidenced in the results found for the nozzle JAP because it showed highest VMD and lowest $\%<100 \mu \mathrm{m}$. The same reasoning but in the opposite direction can be applied to the nozzle ADI. However, such analogy cannot be made for the nozzle J3D because, although it showed intermediate values in comparison to the others, for VMD and $\%<100 \mu \mathrm{m}$, the results indicate lower values of collected drift.

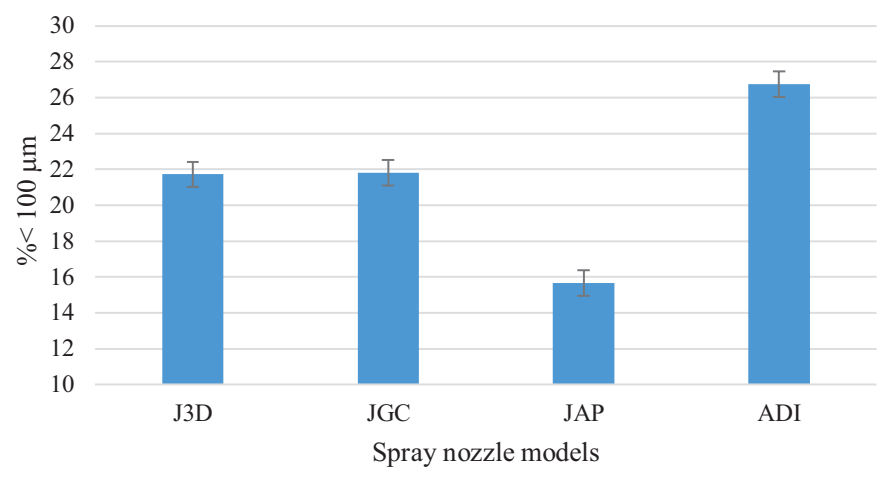

Error bars indicate the confidence interval (Cl 95\%)

Figure 3. Percentage of droplets smaller than $100 \mu \mathrm{m}(\%<100$ $\mu \mathrm{m})$ for the spray nozzles with inclined flat jet (J3D), inclined flat jet with pre-orifice (JGC), second-generation air-induction inclined flat jet (JAP) and flat jet with pre-orifice (ADI)

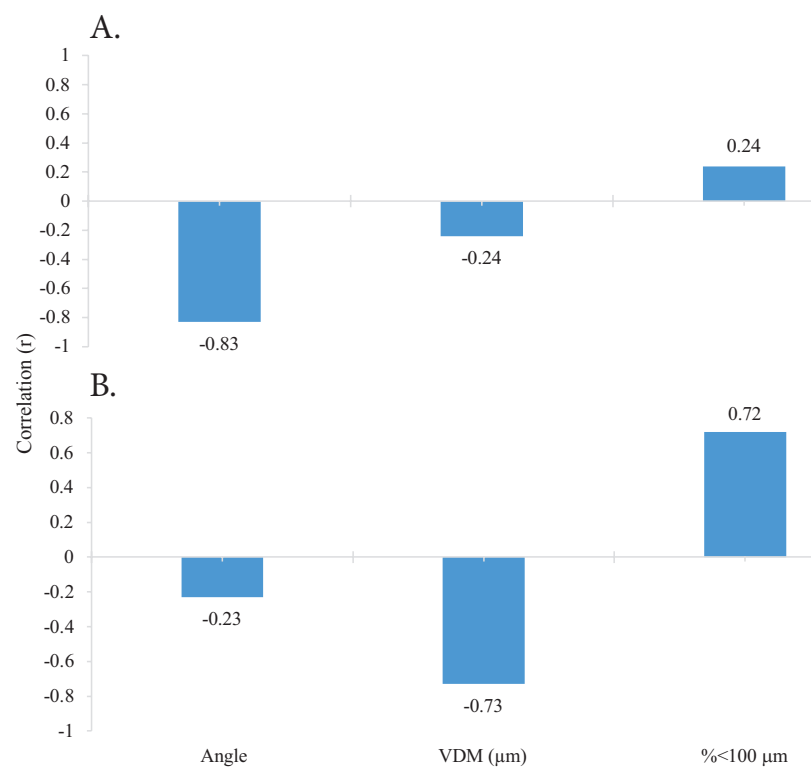

* Pearson correlation significant at 0.05 probability level $(p<0.05)$

Figure 4. Correlation between collected drift with jet angle, VMD and $\%<100 \mu \mathrm{m}$. (A) Against wind flow direction (upwind); (B) Along wind flow direction (downwind)
In the correlation of the data found in the present study, for upwind spraying, it was possible to observe that there is a significant negative correlation of the collected drift mainly with spray nozzle angle (Figure 4A). This means that the increase in jet angle reduces the collected drift. There was low correlation between collected drift and the parameters VMD and $\%<100 \mu \mathrm{m}$.

For the drift collected when the nozzles were positioned with the angle downwind, there is a significant negative correlation with VMD (Figure 4B), i.e., increment in VMD reduces the collected drift. For the parameter $\%<100 \mu \mathrm{m}$, the correlation is positive, strong and significant. This indicates that the increase in collected drift is proportional to $\%<100 \mu \mathrm{m}$, corroborating with Chechetto \& Antuniassi (2012).

\section{Conclusions}

1. Spray nozzles with second-generation air-induction inclined flat jet (JAP) and standard inclined flat jet (J3D) reduce the collected drift in comparison to the nozzle without inclination, regardless of wind flow direction.

2. The spray nozzle inclination angle alone is not sufficient to determine the potential risk of drift, and other factors such as VMD and $\%<100 \mu \mathrm{m}$ should be considered and evaluated.

\section{Literature Cited}

Chechetto, R. G.; Antuniassi, U. R. Espectro de gotas gerado por diferentes adjuvantes e pontas de pulverização. Energia na Agricultura, v.27, p.130-142, 2012.

Chechetto, R. G.; Antuniassi, U. R.; Mota, A. A. B.; Carvalho, F. K.; Silva, A. C. A.; Vilela, C. M. Influência de pontas de pulverização e adjuvantes no potencial de redução de deriva em túnel de vento. Semina: Ciências Agrárias, v.34, p.37-46, 2013. https://doi. org/10.5433/1679-0359.2013v34n1p37

Costa, A. G. F.; Velini, E. D.; Rossi, C. S. R.; Corrêa, M. R.; Negrisoli, E.; Fiorini, M. V.; Cordeiro, J. G. F.; Silva, J. R. M. Efeito de pontas e pressões de pulverização na deriva de glyphosate $+2,4-\mathrm{D}$ em condições de campo. Revista Brasileira de Herbicidas, v.11, p.6270, 2012. https://doi.org/10.7824/rbh.v11i1.143

Cunha, J. P. A. R.; Bueno, M. R.; Ferreira, M. C. Espectro de gotas de pontas de pulverização com adjuvantes de uso agrícola. Planta Daninha, v.28, p.1153-1158, 2010. https://doi.org/10.1590/S010083582010000500023

França, J. A. L.; Cunha, J. P. A. R. da; Antuniassi, U. R. Spectrum, velocity and drift of droplets sprayed by nozzles with and without air induction and mineral oil. Engenharia Agrícola, v.37, p.502509, 2017. https://doi.org/10.1590/1809-4430-eng.agric. v37n3p502-509/2017

Godinho Júnior, J. de D.; Vieira, L. C.; Pereira, L. O. P.; Ruas, R. A. A.; Faria, V. E.; Carvalho Filho, A. Deriva do herbicida 2,4-d aplicado com pontas hidráulicas de jato plano tipo leque. Revista Brasileira de Ciências Agrárias, v.12, p.550-554, 2017. https://doi. org/10.5039/agraria.v12i4a5470

JACTO. Especificações técnicas de modelos de pontas. 2017. Disponível em: <http://www.jacto.com.br/brasil/products/bicosplasticos $>$. Acesso em: Nov. 2017. 
Madureira, R. P.; Raetano, C. G.; Cavalieri, J. D. Interação pontasadjuvantes na estimativa do risco potencial de deriva de pulverizações. Revista Brasileira de Engenharia Agrícola e Ambiental, v.19, p.180-185, 2015. https://doi.org/10.1590/18071929/agriambi.v19n2p180-185

Matuo, T. Técnicas de aplicação de defensivos agrícolas. Jaboticabal: FUNEP, 1990. 139p.

Mota, A. A. B. Espectro de gotas e potencial de deriva de caldas contendo o herbicida 2,4-D amina em misturas em tanque. Botucatu: Universidade Estadual Paulista, 2015. 56p. Tese Doutorado

Oliveira, R. B.; Antuniassi, U. R. Caracterização física e química e potencial de deriva de caldas contendo surfatantes em pulverizações agrícolas. Energia na Agricultura, v.27, p.138-149, 2012.
Oliveira, R. B.; Antuniassi, U. R.; Gandolfo, M. A. Spray adjuvant characteristics affecting agricultural spraying drift. Engenharia Agrícola, v.35, p.109-116, 2015. https://doi. org/10.1590/18094430-Eng.Agric.v35n1p109-116/2015

Simões, R.; Teixeira, M.; Faroni, L. Determinação da uniformidade de distribuição de agroquímicos em grãos de trigo utilizando a técnica da espectrofotometria do uv/visível. Bioscience Journal, v.25, p.130-134, 2009.

Teixeira, E. S.; Osipe, J. B.; Gandolfo, U. D.; Oliveira, J. F.; Gandolfo, M. A.; Osipe, R. Uso de baixo volume oleoso e assistência de ar no controle de plantas daninhas. Semina: Ciências Agrárias, v.31, p.1229-1234, 2010. https://doi.org/10.5433/16790359.2010v31n4Sup1p1229 